\title{
A Brief Overview of Multicultural Education in Ethiopian: A Review
}

\author{
Bezabih Wondimu Kibret (PhD) \\ Assistant Professor in Curriculum Design and Development \\ Department of Curriculum and Teachers' Professional Development Studies \\ College of Education and Behavioral Studies, Madda Walabu University
}

\begin{abstract}
Ethiopia is a country of pluralistic society, having at least eighty nations and nationalities having their own cultures, norms, values, etc. which can be considered as a resource for country's heritage. Multicultural education is designed to address and promote belongingness, equality and recognitions among several different ethnicities in an educational system. It is a field of study and an emerging discipline aims to create equal educational opportunities for students from diverse ethnic, social-class, and cultural groups. Contrary to this fact, however, such diversities had not been given recognition during the former regimes for they used to implement assimilationist ideology. With this regard, the education activities of a country had been carried out from one dominant cultural perspective. However, following the 1994 education \& training policy, major reforms were introduced in the education system of the country. The changes constitute a significant turning point in the history of education of the country. The designing of education system that is responsive to multiculturalism has much importance to the citizens. In general, the underlying goal of multicultural education is to contribute to the transformation of society and to the application and maintenance of social justice and equity. Accordingly, educators, educational theorists, researchers, activists, and everyone else needs to continue to practice and apply multicultural teaching and learning principles both inside and out of the classroom if there is a need to be beneficiary from it at large and to achieve the major goals.
\end{abstract}

Keywords: Historical development, Multicultural education, Multiculturalism

DOI: $10.7176 / \mathrm{JPCR} / 42-02$

Publication date:March $31^{\text {st }} 2019$

\section{Introduction}

\subsection{Nature and Concepts of Multicultural education and Multiculturalism}

Before looking at historical development of multicultural education in Ethiopia, it is helpful to start discussion from the nature and concepts of multicultural education and multiculturalism. This is because knowing the concepts of multicultural education and multiculturalism facilitates understanding of an overviews of historical development of multicultural education and multiculturalism.

Among some of the widely accepted definitions by social scientists, as explained by Banks, (2007), multiculturalism is the co-existence of different cultural groups in one country or state (Banks (2007). For Banks (2007:49), "multiculturalism is a position that rejects assimilation and the "melting pot" image as an imposition of a dominant culture, and instead prefers such metaphors as the Glorious Mosaic' in which each cultural group in the population maintains its distinctiveness".

Further Banks (2007) stated that multi-cultural education in its comprehensive form is about approaches to teaching and learning based up on democratic values that fosters cultural pluralism. As well, it is a commitment to achieve educational equality developing curricula that built understanding about ethnic group. Banks (2007) added that multicultural education can be understood as an educational reform made to bring about equity for all students who come from different social, cultural and linguistic backgrounds.

In support to these viable ideas, Dereje (2016) clearly depicted that multicultural education meant to restructure the curricula and educational institutions in order to support students from diverse background to benefit from equal educational opportunities. Such school reforms strongly challenge and reject discrimination of any sorts in schools and society, and thereby affirm pluralism.

Dereje (2016) and Banks (2007) further explained that multicultural education permits educators to explore to systematic problems that lead to academic failure for many students fosters the design and implementation of productive learning environments, diverse instructional strategies, and a deeper awareness of how cultural and language differences can influence learning.

The concept of multiculturalism was preceded by the concept of cultural pluralism, which was first developed in the 1910s and 1920s, and became widely popular during the 1940s. To these effect, The ideology of multiculturalism was developed between 1960s and 1970s by small number of academicians, social workers, and activists of blacks rights and immigrants welfare, especially in the United States of America and Australia. However, many scholars have written about the cause of the emergence of multicultural education in different words but nearly with the same reasons. Regarding this, Banks (2007) points out that the following three forces 
contributed to the emergence of multicultural education programs, these are:

1. The civil right movement of 1960s and 1970s of USA and Australian immigrants had brought awareness of cultural differences and the need for social change.

2. Formerly prepared school textbooks scrutinized by critics for stereotyping images miss-interpretations and outright omission that they posed about minority groups, and

3. Cultural difference begins to be considered as enriching rather than deficit to be eliminated.

Generally, speaking, the genesis of the concept, on multicultural education came about both in response to the civil rights movements and as expression of the challenges by minority groups against the unequal treatment of students of color and other minority groups in educational and related institutions. Having basic concepts of multicultural education and multiculturalism from world perspectives, therefore, this review try to assess the education system of Ethiopia whether it addresses multicultural education or not since introduction of modern education in Ethiopia.

\subsection{Historical Development of Multicultural Education in Ethiopia (Multicultural Education during Former and Current government)}

Nobody doubts that Ethiopia is a country of culturally, ethnically, linguistically, diverse society (McNab, 2004:41). Adding, the author states that Ethiopia is a country of pluralistic society, having at least eighty nations and nationalities. All of these ethnic groups have their own cultures, norms, values, etc., which should be considered not only as diversity but also as a resource. To this end, it is hoped that education system must be responsive to the needs of ethnic groups; particularly in countries of ethnic, cultural, religious and also other types of diversities. Therefore, it is important to review the historical development of multicultural education in Ethiopia whether the education system of country, Ethiopia, addresses multicultural education or not since the introduction of modern education

\subsubsection{During Emperor Menelik II}

In Ethiopian education history, modern education was introduced during Menelik II in 1908. Following it, modernizing education expanded in Addis Ababa and to the rest provinces. Bezabih (2009), Siyoum (1996) and Mehari (2011) stated that the driving force to introduce and expand modern education during this era were the interest of the Emperor to understand international political order and the need for modernizing the country, Ethiopia, and the need for international interpreters. For this opened schools teachers and schools headmaster were from foreign countries, mostly they were Egyptian and Frenches.

Even though, modern education was introduced at the beginning of $20^{\text {th }}$ century it did not addressed the existing diversity. To witness this fact, Mehari (2011) showed that education practices of a country geared toward one dominant cultural perspective. Besides the explained facts, Siyoum (1996) further condemned Ethiopian education in such a way that, even though Ethiopia experienced modern education during the Emperor Menelik II it was totally resembled western experiences. Especially it was exact copy of French system. Further teachers, and school administrators were from abroad.

Even though Ethiopian education system was a copy of western education, school opportunity was for children of high official class living in urban areas where as rural community were lack such opportunity. According to Tekest (1990) and Robsan (2015) it was perceived that menelik school was not served as instrumental for development, rather it was served political purpose. To cope up with international diplomacy so as to maintain national sovereignty, Ethiopian education was emphasized on language teaching. Languages such as French, Arabic, English, Italian, Ge'eez, and Amharic are included in school curriculum. Bezabih (2009) showed that the fundamental principle that dictated the development and use of school curriculum in this French period was political interest. The curriculum did not well address basic educational, societal, and economic need of the country. Because curriculum was designed by foreigner.

The learning out come to be achieved was not on Ethiopian socio- economic and cultural reality but, it was based on the situation of a country from which advisors, teachers, and school headmasters were used to come. Even if, main subjects were at schools, due emphasis was given for language. This was because languages such as French, Italian, Arabic English etc. were important to maintain international political relations for wellbeing of the emperor and existing aristocracy.

Generally, since the inception of modern education to Ethiopia, the provision of education for its citizens had been mainly characterized by disparities among the diverse nations and nationalities. For instance, during the reign of Emperor Menelik II, the education system was in favor of males, nobilities, and urban people and for ruling classes. Whereas, females, lower class members, rural people, pastoralist society and peasants were denied their right of access to educational opportunities. It was on this basis that MOE (1961) concluded that during the reign of Menelik II, the education system did not fairly serve the diversified nations and nationalities of the country. Further, the content of curriculum was not responsive to the culture values of the nations, nationalities and people of Ethiopia. Thus, the Menelik Regime education system was not fairly address the diversity, so that it was partisan to few class and its content were non Ethiopian values Robsan (2015) and Tekeste (1990). 


\subsubsection{Multicultural Education during Emperor Haileselassie}

The other commitment to education began during the reign of Teferi Mekonnen. Tefer Mekonen was coroneted as Emperor of Ethiopian 1930 by the name of Haileselassie I. following his coronation the majesty Haile Selassie took different reforms in the country, among which education reform was one. Thus, his political leadership stated establishing modern schools' in different provinces in the country, Ethiopia. Schools were opened in Dessie, Harar, Gore, Nekemtie, Dire Dawa, and so on due to many encouraging factors (Bezabih, 2009), Mehari (2011) and Teshome ,1979).

Bezabih (2009) stated that the concern of Education during Haileselassie I was to produce citizens who would be loyal to the king and the country. Education was under the influence of Egypt, Sweden, and USA. The curriculum during this period focused on teaching foreign languages in maintaining the international political relationship useful for the well-being of the emperors and the aristocracy. Only in the last part of this period did some schools include science, mathematics, history, sports in their curricula.

However, the five year Italian invention seriously affect the education system. As a result, schools were destroyed, and used for military purpose, buildings were taken over for Italian children. Teshome(1979), Robsan (2015) and Mehari (2011) clearly explained that only for political purpose that Italian oriented elementary schools were opened and Italian languages and others languages of Ethiopian ethnic group like Amharic, Oromigna, Tigrigna, Harari, Sidama etc. were used as medium of instruction. The curricula developed and implemented during the Italian occupation were for the purpose of achieving Italian ruling class political ambition. However, after Italy was exiled, and following the return of the emperor to the throne from England, British oriented education was introduced. Siyoum (1996), and Tekeste (1990) showed that British influences were highly manifested in Education system of the period. Medium instruction become English, and accepted as official language of the country. Educational materials and personnel including matriculation were from British. As a result, students who succeeded in matriculation were directly sent to universities of Great Britain.

As opposed to the pre-war educational emphasis on the training of foreign languages, the post-war emphasis was to train technicians and professional who would serve the government (Bezabih, 2009). However, in early years of 1950s the influence of British in Ethiopian education system begun declining and gradually substituted by American. Accordingly, 1951-1959 was termed as American Period. Thus, America begun to shape the Ethiopian Education policy through coming into being of education advisory group assimilated into planning committee.

The American period was when there were active participation and involvement of educated Ethiopian were observed. Many Ethiopian Teachers, supervisors, and school administrators were trained to function. Educational reforms come to place into effect to transform academic schools into comprehensive as well as vocational and training education. During this time, education was aimed to produce semi-skilled and skilled man power for different economic activities. Primary education level which encompasses grade 1-6 aimed to enable children to foster traditional values of loyalty and devotion, to emperor, meet urgent need to boost literacy and develop sense of citizenship that help them to foster proper moral and spiritual values. Similarly, secondary schools education was also aimed at guiding the emotion properly, developing inner resources of spirts that brought self-awareness, preparing to participate effectively and efficiently in productive work force of the world. Accordingly, amharic became medium of instruction in elementary schools. Aweke (2015), Bekele (2016), and (Ashenafi 2014) clearly depicted that Haile Selassie heavily and effectively implement education as means of force assimilation to create Amharanized Ethiopian. The time of Emperor Haileselassie was a regime that promoted religious and linguistic homogenization in Ethiopia where Amharic became the only language of primary education and literatures were band in all other languages. Even during Haileselassie times missionaries were obliged to use Amharic language. Furthermore, Amharization became one prerequisite criteria to grant citizenship by law.

According to Mahari (2011) during the period of Haileselassie, the first remarkable progress was made in the education system of Ethiopia in general. It was in this time that:

\$ The curriculum began to relate to the Ethiopian culture and Amharic was selected to serve as a medium of instruction in all primary school of the country. However, the educational system of the country at that time was unfair and lack justice.

\& Supporting this, Tekeste (1990) indicates all instruction in the primary schools was in Amharic, the official language, severely hampered the learning capacity of all those children whose first language was not Amharic.

In summary, as compared to the previous times, remarkable progress was made in the country's education system. By this time, curricular contents were began to be related to the Ethiopian culture; Amharic being medium of instruction in primary schools. Nevertheless, during this time also, the education system did not provide equal educational opportunities for the diversified people of the country.

The empire educational policy was also favored mostly male, predominantly Christian and largely the Amhara and Tigirie ethnic groups. The education system was mainly characterized by the melting pot 
assumption of the dominated Amhara culture dominated. Therefore, the educational system of Emperor Haileselassie could be summarized as the time where the cultural diversities of most of the nations, nationalities and peoples of Ethiopian where undermined. Instead the dominant Amhara culture was dominated the entire education activities of the country.

From all these, we can come up with the fact that education system of country during Haile Selassie was unfair and lack justice. The teaching learning process hammer the learning capacity of non-Amharic nations and nationalities of Ethiopia. Thus, the system violates the right to children to learn using their vernacular language which in turn, affect the right to advance their identity and culture

\subsubsection{Multicultural education during Derge time}

Following the down fall of imperial regime of Haileselassie I, it was Derge that led by military junta who came to power in 1974. Derge declared socialism as socio political and economic system that focus on the doctrine of Marxism and Leninism principles to guide the socio economic and political affair of the country. Numerous resolutions were passed by the state that includes changing the attitude of people involved in educational system, changing the school curriculum, structuring and restructuring the education system.

Derge created strong bond with socialist countries to brought advisors and experts to reform educational policy. The main target of Derge was to serve better interest of the mass and enhance their contribution toward the establishment of socialism. As explained by Bezabih (2009), Mehari (2011), and Robsan (2015) to promote socialism ideology, the ministry of education takes steps to change the curriculum. As a result, in 1981 the military government of Derge launched the General Poly Technique Education Program. Specially to produce fertile ground for the implementation of Marxism Leninism ideology many proclamations were issued and declared. Among this;

$\checkmark \quad$ The 1974 Ethiopia Tikdem

$\checkmark \quad$ The 1974 Ethiopian socialism

$\checkmark \quad$ The 1975 economic guide for socialist Ethiopia and

$\checkmark \quad$ The 1975 land Reform proclamation are few to list.

Bezabih (2009), Tekeste (1990) and Mehari (2011) commented that critics raised during Imperial Haile Selassie time were tried to be corrected by Derge. There was an introduction of educational programs that proved education step by step to the broader mass. All the necessary measures were taken to eliminate illiteracy. However, since the Derge regime persuade socialism-oriented education that indoctrinate Marxism Leninism ideology, the education system of a country was pure pro socialism.

Bezabih still explained that Ministry of Education of Ethiopia introduced National Literacy Campaign which was successful in eradicating illiteracy which in turn contributed much to national development. He further noticed that in line with the implementation of Marxism Leninism educational principles, the following educational policies had been included. These are equal right to education for all members of the society; education for all sided personality; and general and compulsory education for all children of the society. On the other hand, national education objectives include education for production, education for scientific inquiry, and education for socialist consciousness.

Mehari(2011) explained that even though new education reforms were introduced by Derge, there is no difference from that of imperial time, by using education for political purpose education as instrument for creating assimilated Ethiopian. Tekeste (1990) showed that Derge forced Ethiopian student to be indoctrinated with Marxism Leninism socio economic and political ideology. Thus Derge continued the assimilationist policy started by Haileselassie with new version of Ethiopia tikdem. By Derge time, Amharic become the only language used as medium of instruction. It is possible to say that Derge repeated the empirical time negligence to address diversity to maintain stability and equality among Ethiopian nation, nationality and people. Thus, Derge deny the right to equality, self-determination, and strongly uphold assimilation that further marginalize many of nations and nationalities of Ethiopia.

In summary, the Derge education system was characterized by high centralized socialist ideology in which schools were obliged to produce citizens that are loyal to socialist principles. Simply the Derge regime proclaimed the existence nations nationalities and people with their unique culture languages, and their equal rights in the countries overall activities for his political advantage. Because the educational system of the country was highly centralized by the socialist ideology, for this Amharic was serving as a medium of instruction for the assimilation of different cultures of the country.

To sum up, as to the previous regimes, the Derge education system was also characterized by its melting pot assumption provision of education from one dominant culture, except better expansion of education to the rural parts of the country when compared to the prior regime.

\subsubsection{Multicultural Education during FDRE since 1991}

After the Derge regime was thrown from the throne in 1991, the present-day government has come to power and introduced the so called the Education and Training Policy in 1994. Based on the analysis conducted regarding the education system of the past time, the policy come up with well identified major problems that demand 
reforms and immediate intervention. These includes;

Equitable access to primary and vocational education

Restructuring the education system

Changing the existing curriculum to increase relevance of education for community

Improve the quality of education

Tekeste (1990), and FDRE (1994) explained that alongside of reforms re-structuring and structuring where introduced so that the previous 6, 2, 4 (grade 1-6 elementary schools, grade 7and 8 Junior secondary schools and grade 9 to 12 high schools) structure was changed to 4, 4, 2, 2, that stands for grade 1-4 lower primary school; grade 5-8 upper primary school, grade 8 and 9 lower high schools and grade 11 and 12 preparatory schools. For students up to grade 3 automatic promotions was introduced as well up to grade 8 mother tongue is used as medium of instruction. General education up to grade 10 is provided freely for children while from grade 11 to higher education is provided based on cost sharing strategy.

As it was indicated in policy document, education system shall be democratic, decentralized, efficient and effective in its output (Moe, 1994). Based on this guiding principle, the policy come up with five general objectives, 15 specific objectives and 9 implementing strategies. The general objective of the policy as it is taken from policy document are presented here below (FDRE, 1994).

- Develop the physical and mental potential and problem-solving capacity of individuals by expanding education and in particular by providing basic education for all.

- Bring up citizens who can take care of and utilize recourses wisely, who are trained in various skills, by rising the private and social benefits of education.

- Bring up citizens who respect human rights, stand for the well-being of people, as well as for equality, justice and peace, endowed with democratic culture and discipline.

- Ones, who seek and stand for truth, appreciate aesthetics and show positive attitude towards the development and dissemination of science and technology in society.

- Cultivate the cognitive, creative, productive and appreciative potential of citizens by appropriately relating education to environment and societal needs.

Similarly, the policy encompasses nine strategies that related with the curriculum, educational structure, measurement and examinations, teachers, language and education, nexus between education, training and research and development, education support inputs, education organization and management, and finance were well addressed (FDRE, 1994).

Following implementation of the policy, significant changes were introduced in country education system. Thus, education system of Ethiopia during FDRE become responsive to multicultural education. Few of these multicultural responsive reforms introduced includes: Provision of primary education with mother tongue, because it is witnessed that education with mother tongue is pedagogically sound and significant. Since child do not face language problem to understand his environment. Another fact is that nation nationality and people of Ethiopia are granted the right to nurture their language, culture, and history as indicated in article 39 of the 1995 constitution. Further article 39 (2) explained that every nation, nationality and people of Ethiopia has the right to speak, to write, to develop its own language, to express, to develop and to promote its culture, and to preserve its own history (FDRE, 1995).

Furthermore, the constitution reflected that the government shall have the duty to support, on the basis of equality, the growth and enrichment of cultures and traditions that are compatible with fundamental rights, human dignity, democratic norms and ideals, and the provisions of the constitution (Federal Democratic Republic of Ethiopia,FDRE, 1995, Article 91). In addition, the constitution declares that education shall be provided in a manner that is free from any religious influence, political partisanship or cultural prejudices (FDRE, 1995, Article 90).

One of the subsequent policies developed to facilitate the implementation of the constitution is the education and training policy of Ethiopia. With respect to issues of diversity, the education and training policy states to provide education that promotes democratic culture, tolerance and peaceful resolutions of differences that raises the sense of discharging societal responsibility. In addition, the same education and training policy underscores to provide education that can produce citizens who stand for democratic unity, liberty, equality, dignity and justice, and who are endowed with moral values (FDRE, 1994).

Cognizant of the advantages for pupils of learning in their mother tongue and the rights of nations and nationalities to promote the use of their languages, the 1994 education and training policy of the country permitted the use of nationalities' languages as media of instruction in primary education, that is, grades 1-8 (FDRE, 1994).

In short, as a result of the government change in 1991, the language policy of the country was changed from a monolingual to a multilingual one (Mehari, 2011). This implied a change from using Amharic as the only medium of instruction in the entire country to using vernacular languages as media of instruction at the primary school level and in the teacher preparation programs for preprimary and primary education. 
Robsan (2015) stated that following these major ideological changes, 22 out of the 83 indigenous languages have been used as media of instruction in the primary schools until to date. This limited use of the vernacular languages as media of instruction, amongst other things, may emanate from the fact that using an ethnic group's language as a medium of instruction particularly from scratch requires having adequate stocks of, for instance, dictionaries, textbooks, glossaries, and other literature.

In addition, Robsen (2015) showed that a new cultural policy was introduced in 1997 to further ensure equal recognition, respect, and promotion of the cultures as well as the languages of all the nations, nationalities and peoples of Ethiopia as enshrined in the constitution. Another important development that can contribute to the strengthening of multicultural education is the official annual national celebration of the Ethiopian Nations, Nationalities and Peoples Day' that has taken place for the last nine years. The Ethiopian government is celebrating the day, amongst other things, to foster exchange of good experiences and practices among the members of the diverse Ethiopian society as a means to promote ethno-cultural and linguistic recognition, mutual understanding, tolerance and peaceful co-existence.

In addition, the broadcasting of various programs that reflect the diverse cultures and languages of the peoples of Ethiopia through the mass media of the country can be considered as another important input for the promotion of multicultural education.

In general, with the advent of the FDRE, government the Education and Teaching policy was introduced in the education system of the country which gave legal ground for all nations, nationalities and peoples to enjoy equal rights in the countries education system. To this end, the media of instruction at primary schools first cycle changed from Amharic to mother tongue of nations and nationalities except in some regions. The contents of the curriculum are developed to reflect the cultural base of community (Tekeste, 1990).

This shows that the Education and Training policy provided legal ground for nations and nationalities and peoples of Ethiopia to participate equally in the education system of the country. From this, one can understand that the Ethiopian Education systems come across different challenges to have the present/existing/ feature.

\section{References}

Ashenafi R. (2014). Integration of Multicultural Content in Civic and Ethical Education Preparatory level Text book. A Thesis submitted for the partial fulfilment of Masters of Art in Curriculum Study. Addis Ababa University.

Aweke Shishigu(2015). Foundation of Curriculum in Ethiopia: Historical, Philosophical, Psychological and Sociological Perspectives. Bahir Dar University, Ethiopia.

Bank (1999). An Introduction to Multicultural Education.2 ${ }^{\text {nd }}$. ed. Boston: Allyn and Bacon.

Banks J.A. (2007). An introduction to Multi Culture Education: An Overview of the Issues and Concepts related to Multicultural Education.

Bekele. T. (2016). State Society Relation in Ethiopia. A Political Economy Perspective Post 1991 order.

Bezabih Wondimu (2009). Multicultural Education: Distance education material for summer in-service trainees. Madda Walabu Univesrity. Bale -Robe

Dereje T.(2016). Imperative of Multi Cultural Education in Ethiopia: Reflection on Awareness, Practices and Challenges on Higher Learning. Ethiopian Civil Service University.

FDRE (1994). Education and Training Policy. Addis Ababa: St. George Printing Press.

Federal Democratic Republic Of Ethiopia (1995). Ethiopian Constitution.

Gay, Geneva (1994). A Synthesis of Scholarship in Multicultural Education. University of Washington-Seattle.

Girma H. (2001). "Ministry of Education in Ethiopia." Africa Revista Time in Role de Studie Documentizatione del Instituto Italo-Africano, 37(3).

McCormick C. (1984). Multicultural Education Connecting Theory to Practice. In focus On Basics: Connecting $\begin{array}{lllll}\text { Research } \quad \text { Pnd } & \text { Volume } & \text { Issue } & \text { B. }\end{array}$ http://findarticles.com/p/articles/mi_qa3935/is_200101/ai_n8948129/

McNab E. (2004). Multiculturalism and Multicultural Education in an International Perspective. Leiden University. Access provided by Addis Ababa University, JSTOR Antropology \& Education Quarterly vol.27,No.3.

Mehari Y. (2011). Ethiopia Multicultural Education: Negotiation to past and Champions of the New Beginning in National building. Addis Ababa.

Ministry of Education (1994). Ethiopian Education Policy. Addis Ababa

MoE (2002). Education Policy and Its Implementation. Addis Ababa: Mega Publishing Enterprise.

Neito, S. (1999). Multicultural Education - History, The Dimensions of Multicultural Education, Evidence of the Effectiveness of Multicultural Education.http://education.stateuniversity.com/pages/2252/MulticulturalEducation.html">

O' Neil S. (2006). Multicultural education for children: Theory and Practice. Boston: Allyn and Bacon.

Robsan Margo (2015).Ethiopia in transition: A multi-cultural Perspective on Teacher Education policies, 
curricula, and Practices.. University of Oslo.

Schain, J.(2004). Dimensions of Multicultural Education. New Delhi,India: Scholarly brole press.

Seyoum Teffera (1996). Education and Development In Ethiopia. vol. 8, No.2 Ethiopian Economic Association. Tekeste Negash (1990). Education in Ethiopia: From Crisis to the Brink of Collapse. Uppsala. Uppsala University Press

Teshome G. (1979).Summative Evaluation of Primary (1-8) Curriculum at Implementation Stage (SEPC). Curriculum Evaluation Panel, Curriculum Evaluation and Educational Research Coordination.

Tyler D. (2004). Implications of Multiculturalism for Education: The Canadian Context. University of Saskatchewan Saskatoon, SK. Canada. 